\title{
Research on Online Shopping Intention of Undergraduate Consumer in China--Based on the Theory of Planned Behavior
}

\author{
Dan Su \& Xu Huang \\ School of Business Administration, Southwestern University of Finance and Economics \\ E-mail: suninfeng7@163.com
}

\begin{abstract}
Based on the Theory of Planned Behavior, this research is to construct a logit model on online shopping intention of undergraduate consumer and discuss the main influential factors and extent on that. We find out it is greatly influenced by price of goods and the student's knowledge on computer and online currency clearing. We finally propose relevant suggestions and countermeasures for buyers and suppliers of online shopping.
\end{abstract}

Keywords: Online Shopping, Shopping Intention, Theory of Planned Behavior

Along with wide spreading and application of Internet, online shopping has increasingly obtained attentions from every social community as a new type of consumption mode. According to "the 25th China Internet Development Statistics Report" (Hereinafter referred to as the "Report") issued by CNNIC (China Internet Network Information Center), China has 108 million online shopping users in 2009 with 45.9\% annual growth rate. Online shopping usage rate was $22.1 \%$ by the end of 2007 , while it has reached to $28.1 \%$ at present. Although online shopping usage rate is increasing annually, its increase rate ranks at bottom among business network application. The low annual increase rate of online shopping is caused by deeper reasons, such as network security and consumer perceived risks. Compared to traditional shopping consumers, online shopping consumers have their own behavior ways and characteristics. Their purchase motivation and intention, and the influential factors are all quite different. Furthermore, according to relevant statistics, 32.3\% of Internet users are students by the end of 2006. The total amount of students' online shopping in six months is 3.1 billion which accounts for one quarter of those of non-students by the end of July, 2008. Therefore, we choose undergraduates who can best represent student group as research object in order to study their online shopping motivation and the process of decision-making, and to identify the main influential factors on that.

\section{Literature Review}

\subsection{International Research}

On consumer online shopping intention, non-Chinese scholars have made a great deal of research. Forsythe \& Shi (2003) and Teo \& Yeong (2003) respectively discussed many influential factors on online shopping. Koyuncu and Bhattacharya (2004) studied the influence of responsive sensitivity, price, payment risk and delivery on individual online consumption decision-making and consumption frequency. Rohm and Swaminathan (2004) classified online consumers based on buying intention. Cass and Fenech (2003) studied the behavior mechanism of Internet user's online consumption. Hsu et al. (2006) made a vertical research on consumer's continuous online shopping behavior, and expanded the Theory of Planned Behavior. Lian and Lin (2008) analyzed the influence of consumer's characteristics on online consumption under condition of different product type and service. Farag et al. (2007) applied structure equation model to analyze the relationship between online shopping and store shopping. Lee and Kwon (2008) utilized cause and effect graph method to analyze online shopping recommendation system and its influence on consumer's decision-making and behavior.

\subsection{Relevant Research in China}

Han Yanmin (2007), a Chinese scholar, established multilayer SEM model to analyze consumer online shopping intention, and pointed out perceived risk is the key factor influencing consumer online shopping. Other scholars, He Qiguo and Lin Meihua(2006), Sun Qiang and Si Youhe (2007) respectively applied structure equation, constituted model of customer perceived value and other different research methods to analyze the attitude and Internet experience which probably influence consumer online shopping. Yin Shijiu et al. (2008) studied consumer online shopping intention by using the Theory of Planned Behavior and Logit model. Xu Heqing and Jie Xinhua (2009) utilized factor analysis and multiple regression analysis to discuss the main influential factors on consumer online shopping.

After reviewing all the above research, we find out, although scholars have studied a lot on consumer online shopping intention, motivation and decision-making, they seldom make particular online shopping research on undergraduates, this special consumer group. Thus this paper is to regard undergraduates as research object so as to 
fill in the vacancy, theoretically contribute to online shopping research, and propose relevant suggestions for online shopping buyers and suppliers in order to promote healthy and orderly development of undergraduate's online consumption.

\section{Theoretical Frame and Research Hypothesis}

\subsection{Theoretical Frame}

We shall make an analysis based on the Theory of Planned Behavior (TPB) (Ajzen, 1988, 1991) which is an extension of TRA and used for explaining and forecasting individual acceptance to IT(Huang and Chang, 2005; Wu and Chen, 2005). According to TPB, individual consumption behavior depends on consumption intention and perceived behavioral control, and consumption intention depends on attitude (A), subjective norm (SN) and perceived behavioral control (PBC). Attitude reflects advantageous or disadvantageous feeling when someone is doing something. SN reflects the perception of someone on others' opinion of whether he should perform a particular behavior, i.e. others' agreement on the consumption behavior, which means others put forward consumption "norm" for the consumer. PBC reflects someone's perception on the availability of resources or opportunities of performing a behavior (Ajzen and Madden, 1986), i.e. consumer's judgment on his own feasible consumption degree. The third layer is to analyze the influential factors of the above attitude, "norm" and judgment. The three structural layers of TPB show the progressive relationships. And the fundamental influential factor on consumption decision-making is the third layer. All these factors compose the core of the whole theoretical frame. Therefore, we think, we can start from the third layer of TPB and analyze the main influential factors on undergraduate's online shopping intention from buyer perspective when buying behavior happens.

Generally speaking, compared to other consumption group, some undergraduates' basic conditions enable them choose online shopping, fashionable consumption, more in reality. Additionally, undergraduates' leisure, young people's curiosity and hyperactivity, and unlimited Internet are all probably their driving force without getting bored. Based on the Theory of Planned Behavior, we shall start from the conditions that undergraduate consumers have per se and their comment on online shopping to consider the main influential factors on undergraduate online shopping, which will be corresponding to the three layers of the Theory of Planned Behavior and the interaction among them.

\subsubsection{Comment on Online Shopping}

This section mainly consists of the comment on online shopping security and convenience, as well as other advantages. As online shopping is processed in a virtual environment, and logistics, information flow and capital flow are completed in a time and space separation, it has uncertainty and risks. Järvenpää et al. (1999) thought the lack of security of online shopping is the main reason why consumers give up purchase. Lim (2003) claimed if the sense of security that consumers have on online shopping is lower, the risk anticipation will be higher and online shopping participation degree will be lower. Miyazaki and Fernandez (2001) pointed out; the Internet intimate security is the main barrier of consumer online shopping. Online shopping security is reflected in currency clearing, delivery and consumer information. Online shopping convenience is mainly reflected in shorter time and less energy spent, including transportation cost reduction, less crowd and queues than real markets, unlimited time and space, which all increase convenience of shopping. The competitive advantages that online shopping consists of are: firstly, price. Because online shops are virtual, rent cost of store is reduced. The shrinking of supply chain reduces profit plus, which brings lower price of goods. Secondly, goods information advantages. In traditional real stores, no matter how big they are, what they can contain is limited. And customers have to go to the real stores to learn the relevant information of goods. However, Internet is the display platform of goods and a kind of virtual space. As long as you have goods, you can display them on this platform and customers can learn all the information of goods so as to make a purchase decision. Thirdly, customers can interact with goods' suppliers online.

\subsubsection{Conception, Knowledge and Capacity of Consumer Online Shopping}

Undergraduates belong to high-degreed groups, so their computer knowledge and online currency clearing knowledge are better than other low-degreed ones. They have stronger online shopping intention and more shopping modes as well. Additionally, the transformation of undergraduates' shopping conception and their ability to distinguish product authenticity both influence whether they do online shopping.

\subsection{Research Hypothesis}

We shall raise the following hypothesis based on the influential factors on undergraduate's online shopping intention.

\subsubsection{The Influence of Online Shopping Comment on Undergraduates' Intention}

Hypothesis 1: undergraduates' comment on online shopping security is positively correlated to online shopping 
intention; Hypothesis 1a: Internet currency clearing security is positively correlated to online shopping intention; Hypothesis $1 \mathrm{~b}$ : transaction security is positively correlated to online shopping intention; Hypothesis 1c: security of consumer's personal information is positively correlated to online shopping intention. Hypothesis 2: undergraduates' comment on online shopping convenience is positively correlated to online shopping intention. Hypothesis 3 : advantages of online shopping is positively correlated to online shopping intention of undergraduates; Hypothesis 3a: price advantage is positively correlated to online shopping intention; Hypothesis $3 \mathrm{~b}$ : advantage of obtaining product's information is positively correlated to online shopping intention; Hypothesis 3c: advantage of interacting with suppliers is positively correlated to online shopping intention.

2.2.2 The Influence of the Conception, Knowledge and Ability of Online Shopping on Undergraduate Online Shopping Intention

Hypothesis 4: the conception, knowledge and ability of online shopping is positively correlated to online shopping intention; Hypothesis 4a: the transformation of online shopping conception is positively correlated to online shopping intention; Hypothesis 4b: computer knowledge and Internet currency clearing knowledge of undergraduates are positively correlated to online shopping intention; Hypothesis $4 \mathrm{c}$ : the ability to distinguish product authenticity is positively correlated to online shopping intention.

According to the above analysis on the main influential factors on undergraduate online shopping, referring to relevant research findings of both Chinese and international scholars, and from the Theory of Planned Behavior perspective, we achieve the theoretical frame of this paper, see Figure 1.

Insert Figure 1 Here

\section{Research Design and Data Analysis}

\subsection{Sample and Data Collection}

The research objects are undergraduate consumers. The questionnaires were distributed by e-mails and QQ. Through the author's acquaintances or schoolmates, we distributed questionnaires to the undergraduates interested in online shopping. We sent out 70 questionnaires and received 68. Except ineffective or wrong-written questionnaires, effective ones are 60 in total, which accounts for $85.71 \%$.

\subsection{Measurement of Variables}

\subsubsection{Independent Variable}

We define independent variable as 10 influential factors on undergraduate online shopping, which are Internet currency clearing security, transaction security, security of consumer's personal information, comment on online shopping convenience, price advantage, advantage of obtaining product's information, advantage of interacting with suppliers, transformation of online shopping conception, computer knowledge and Internet currency clearing knowledge of undergraduates, the ability to distinguish product authenticity. We shall apply Five-point Likert Scale to measure the influential factors on undergraduate online shopping.

\subsubsection{Dependent Variables}

The purpose of this paper is to analyze the main influential factors on undergraduate online shopping intention, so the final explained variable is whether an undergraduate will do online shopping. The result will be binary discrete $(0-1)$ dependent variable (when $y=1$, it means online shopping; when $y=0$, no online shopping). We assume that the possibility of $\mathrm{y}=1$ is $\mathrm{p}$, thus the distribution function of $\mathrm{y}$ is:

$$
E\left(Y_{i}\right)=E\left(Y_{i} \mid X\right)=\operatorname{Prob}\left(Y=1 \mid X_{i}\right)=p_{i} \quad i=1,2, \cdots, n
$$

The dependent variable in this research is the probability of undergraduate online shopping, so it is valued in $[0,1]$. We make parameter estimation by maximum likelihood estimation. The basic form of Logit model is as follows:

$p=P\left(y=1 / X_{1}=x_{1}, \ldots, X_{n}=x_{n}\right)=\frac{e^{\beta_{0}+\beta_{1} x_{1}+\ldots+\beta_{n} x_{n}}}{1+e^{\beta_{0}+\beta_{1} x_{1}+\ldots+\beta_{n} x_{n}}}$

$\mathrm{P}$ is conditional probability, i.e. on conditional of $X_{1}, X_{2}, \ldots, X_{n}$, the probability of $\mathrm{y}=1$.

According to the above hypothesis, we construct the function between the 10 influential factors and undergraduate online shopping intention: the undergraduate online shopping intention $=\mathrm{f}$ (Internet currency clearing security, transaction security,) + Random disturbance term. See Table 1 for the details.

Insert Table 1 Here 


\subsubsection{Reliability Test}

According to Nunally (1978) standard, $\alpha>0.9$ represents very good reliability, $0.7<\alpha<0.9$ means high reliability, $0.35<\alpha<0.7$ refers to medium reliability, and $\alpha<0.35$ represents low reliability. Generally speaking, the value beyond 0.70 represents the reliability of sample data passes test (Li Huaizu, 2004). We take Cronbach $\alpha$ coefficient as test standard and start from hierarchical idea of scale to test the internal consistency reliability of the scale based on its consistency of the internal structure.

In this research, the variable's Cronbach $\alpha$ coefficient is over 0.7 , which is in accordance with the test standard, so the test result indicates the reliability of each scale is rather high.

\subsection{Research Result}

We applied SPSS17.0 to make Logit regression on sample data. During processing data, we take all variables into regression function to make significance test on regression coefficient. The result is shown in Table 2.

Insert Table 2 Here

\section{Result Discussion and Proposals}

\subsection{Result Discussion}

From the estimated result of Table 2, we can see price advantage most influences online shopping intention of undergraduates (except constant), which should be determined by the characteristics of this consumer group. As we know, undergraduate consumers have no income source usually, but get money from parents, so under condition of limited cost of living, based on economics maximum benefit with limited cost (or income) principle, we think undergraduates will choose certain approaches (like Internet) to buy cheaper products, which is consistent with our result.

Furthermore, computer knowledge and Internet currency clearing knowledge that undergraduates have are comparatively significant on online shopping. Yin Shijiu et al. (2008) achieved same result as ours. They pointed out; Internet application skills significantly influence online shopping. As a new emerging shopping mode, Internet requires consumers grasp relevant computer and Internet currency clearing knowledge and skills. The undergraduate consumer group meets this basic requirement of online shopping. Most of undergraduates attend the course of college computer basics (probably in another course name, but similar content). They study some basic Internet operation knowledge, which establishes foundation for online shopping. Along with increased Internet experience, undergraduates grasps more online shopping skills and information source, so that they are more likely to do shopping online. Miyazaki and Fernandez (2001) claimed, although risk is an important reason that hampers online shopping, most of perceived risks comes from consumer's being unfamiliar with the completely new and long-distance shopping way. So Internet experience and skills can reduce perceived risks and increase shopping intention and real purchase.

Other factors, such as online shopping security and convenience, other online shopping advantages (advantage of obtaining product's information and advantage of interacting with suppliers), transformation of online shopping conception and the ability to distinguish product authenticity, don't significantly influence online shopping intention of undergraduates. These indicate online shopping security and convenience are widely approved by undergraduate consumers, while price is more important. So the other advantages become insignificant compared to price advantage. Transformation of online shopping conception has little influence on online shopping intention. Most investigated students have online shopping experience, so the transformation of online shopping conception has become unimportant. The ability to distinguish product authenticity has insignificant influence on online shopping intention, because the service after sale provided by sellers (online shops) are quite good and what they assure makes buyers comfortable. So consumers can't perceive any difference from real shopping (for instance, a seller promises unconditional return within seven days on dissatisfaction), so the ability to distinguish product authenticity is really unimportant.

\subsection{Proposals}

What we have analyzed shows the online shopping intention of undergraduate is mainly influenced by price advantage and computer and Internet currency clearing knowledge. In the development of promoting Chinese undergraduate's online shopping, we should systematically consider various factors. Based on the above, we propose as follows:

\subsubsection{Strengthen Construction of Online Shopping Advantages}

Besides the basic price advantage of online shopping, we also need to strengthen the communication and interaction with customers, develop consumer investigation by low-cost network, provide with customized online products and 
service, and instruct consumers for purchase decision, so as to promote wide and deep development of individuation service. For example, Dangdang website often recommends other popular books to consumers according to their previous buying record.

\subsubsection{Strengthen Basic Internet Skill Training.}

Undergraduates should be inducted to transform conception and try new things. We need to strengthen their cognition and understanding on online shopping and increase their ability to distinguish product authenticity. Also we should strengthen consumption education to promote their rights maintaining ability to sellers (online shops), consciousness and positivity.

\subsubsection{Strengthen Construction of Online Shop Image}

As far as online shopping is concerned, we have to reduce consumer's perceived risks and increase reliability of online shopping in order to transform consumers from "Brower buyers" into real buyers. We propose price guarantee, free sample, return guarantee, third-party check and word of mouth, in order to reduce consumer's perceived risks and further good awareness and reputation of websites. So that more undergraduates can be attracted by online shopping.

Note:

(1) Iresearch defines online shopping as the transfer process of product or service from a shop/seller to a buyer (consumer) by means of network. In the whole process, for capital flow, logistics and information flow, if any link involves network, it would be called online shopping.

(2) Take the comparison between 2008 and 2009 as a case. In business application (including online shopping, online bank, online payment, online stocks and travel reservation), the annual growth rate of online payment ranks first, followed by travel reservation, and then followed by online stocks and online bank. The last one is online shopping.

\section{References}

Ajzen, I. (1988). Attitudes, Personality, and Behavior [M]. Chicago.IL. Dorsey Press.

Ajzen, I. (1991). The theory of planned behavior. Organizational Behavior and Human Decision Processes. 50 (2):179-211.

Ajzen, I., Madden, T.J. (1986). Prediction of goal-directed behavior: Attitudes, intention and perceived behavioral control. Journal of Experimental Social Psychology. 22(5): 453-474.

Baidu Encyclopedia. Online shopping [EB / OL]. http://baike.baidu.com/view/7777.htm?fr=ala0_1_1.

Cass, A. O., Fenech, T. (2003). Web retailing adoption: Exploring the nature of Internet user's web retailing behavior [J]. Journal of Retailing and Consumer Services. 2003, 10(2): 81-94.

China Internet Network Information Center. China Internet Development Statistics Report. 2008. (1): 39.

China Internet Network Information Center. China Internet Development Statistics Report. 2010. (1): 37-38.

China Internet Network Information Center. China Internet Development Statistics Report. 2007. (1): 52.

Farag, S., Schwanen, T., Dijst, M., Faber, J. (2007). Shopping online and/or in-store? A structural equation model of the relationships between e-shopping and in-store shopping. Transportation Research Part A: Policy and Practice. 2007. 41(2): 125-141.

Forsythe, S.M., and Shi, B. (2003). Consumer patronage and risk perceptions in Internet shopping]. Journal of Business Research.2003. 56(11): 867-875.

Han, Yanmin. (2007). Consumer online shopping intentions for multi-SEM model. Statistics and Decision.2007. (4): 9-11.

He, Qiguo and Lin, Meihua. (2006). Empirical Study on Online Shopping Behavior. Economic Management. 2006. (10): 44-49.

Hsu, M.H., Yen, C.H., Chiu, C.M., Chang, C.M. (2006). A longitudinal investigation of continued online shopping behavior: An extension of the theory of planned behavior. International Journal of Human-Computer Studies. 64(9): 889-904.

Hung, S.Y., Chang, C.M. (2005). User acceptance of WAP services: Test of competing theories [J]. Computer Standards \& Interfaces. 2005.27(4): 359-370.

Järvenpää, S.L., Tractinsky, N., Saarinen, L., Vitale, M. (1999). Consumer trust in an Internet store: A cross-cultural validation. Journal of Computer-Mediated Communication. 5(2): 1-5. 
Koyuncu, C., Bhattacharya, G. (2004). The impacts of quickness, price, and payment risk, and delivery issues on on-line shopping. Journal of Socio-Economics. 33(2): 241-251.

Lee, K. C., Kwon, S. (2008). Online shopping recommendation mechanism and its influence on consumer decisions and behaviors: A causal map approach. Expert Systems with Applications.35(4): 1567-1574.

Li, Huaizu. (2004). Management Methodology. Xi'an: Xian Jiaotong University Press.

Lian, J.W., Lin, T.M. (2008). Effects of consumer characteristics on their acceptance of online shopping: Comparisons among different product types. Computers in Human Behavior. 24(1): 48-65.

Lim, N. (2003). Consumer's perceived risk: Source versus consequences. Electronic Commerce Research and Application. 2(3): 216-228.

Miyazaki, A.D., and Fernandez, A. (2001). Consumer perceptions of privacy and security risks for online shopping. Journal of Consumer Affairs. 35(1): 27-44.

Nunnally, J.C. (1978). Psychometric theory (2nd ed.). New York: McGraw-Hill.

Rohm, A. J., Swaminathan, V. (2004). A typology of online shoppers based on shopping motivations. Journal of Business Research. 57(7): 748-757.

Sun Qiang and Si Youhe. (2007). On form of customer perceived value of Online shopping. Technology Management Research. (7): 185-187.

Teo, T. S.H., and Yeong,Y.D. (2003). Assessing the consumer decision process in the digital marketplace. International Journal of Management Science. 31(5): 349-363.

Wu, I.L., Chen, J.L. (2005). An extension of trust and TAM model with TPB in the initial adoption of on-line tax: An empirical study. International Journal of Human-Computer Studies. 62(6): 784-808.

$\mathrm{Xu}$, Heqing and Jie, Xinhua. (2009). Main influential factors on consumers online shopping. Consumer Economics. 25 (2): 38-41.

Yin, Shijiu, Wu, Linhai and Du, Lili. (2008). On consumer online shopping intention based on the theory of planned behavior. Consumer Economics. 24. (4): 35-39.

Table 1. Description of Variables

\begin{tabular}{|c|c|c|c|}
\hline Name of Variables & Definition of Variables & Means & $\begin{array}{l}\text { Standard } \\
\text { Deviation }\end{array}$ \\
\hline \multicolumn{4}{|l|}{ Variables } \\
\hline $\begin{array}{l}\text { Comment on Internet currency } \\
\text { clearing security }\left(\mathrm{X}_{1}\right)\end{array}$ & $\begin{array}{l}1=\text { very dangerous } \quad 2=\text { dangerous } \\
3=\text { general } \quad 4=\text { safe } \quad 5=\text { very safe }\end{array}$ & 4.22 & 0.691 \\
\hline $\begin{array}{l}\text { Comment on transaction security } \\
\left(\mathrm{X}_{2}\right)\end{array}$ & $\begin{array}{l}1=\text { very dangerous } \quad 2=\text { dangerous } \\
3=\text { general } \quad 4=\text { safe } \quad 5=\text { very safe }\end{array}$ & 3.98 & 0.792 \\
\hline $\begin{array}{l}\text { Comment on security of } \\
\text { consumer's personal information } \\
\left(\mathrm{X}_{3}\right)\end{array}$ & $\begin{array}{l}1=\text { very dangerous } \quad 2=\text { dangerous } \\
3=\text { general } \quad 4=\text { safe } \quad 5=\text { very safe }\end{array}$ & 3.67 & 0.914 \\
\hline $\begin{array}{l}\text { comment on online shopping } \\
\text { convenience }\left(\mathrm{X}_{4}\right)\end{array}$ & $\begin{array}{l}1=\text { very inconvenient } \quad 2=\text { inconvenient } \\
3=\text { general } \quad 4=\text { convenient } \quad 5=\text { very convenient }\end{array}$ & 4.02 & 0.770 \\
\hline price advantage $\left(\mathrm{X}_{5}\right)$ & $\begin{array}{l}1=\text { very small } \quad 2=\text { small } 3=\text { general } \\
4=\text { big } \quad 5=\text { very big }\end{array}$ & 4.10 & 0.706 \\
\hline $\begin{array}{l}\text { advantage of obtaining product's } \\
\text { information }\left(\mathrm{X}_{6}\right)\end{array}$ & $\begin{array}{l}1=\text { very small } \quad 2=\text { small } 3=\text { general } \\
4=\text { big } 5=\text { very big }\end{array}$ & 4.07 & 0.710 \\
\hline $\begin{array}{l}\text { advantage of interacting with } \\
\text { suppliers }\left(\mathrm{X}_{7}\right)\end{array}$ & $\begin{array}{l}1=\text { very small } \quad 2=\text { small } 3=\text { general } \\
4=\text { big } \quad 5=\text { very big }\end{array}$ & 3.42 & 0.766 \\
\hline $\begin{array}{l}\text { transformation of online shopping } \\
\text { conception }\left(\mathrm{X}_{8}\right)\end{array}$ & $\begin{array}{l}1=\text { very weak influence } 2=\text { weak influence } 3=\text { general } \\
4=\text { strong influence } 5=\text { very strong influence }\end{array}$ & 3.93 & 0.821 \\
\hline $\begin{array}{l}\text { computer knowledge and Internet } \\
\text { currency clearing knowledge }\left(\mathrm{X}_{9}\right)\end{array}$ & $\begin{array}{l}1=\text { very weak influence } 2=\text { weak influence } 3=\text { general } \\
4=\text { strong influence } 5=\text { very strong influence }\end{array}$ & 3.93 & 0.710 \\
\hline $\begin{array}{l}\text { ability to distinguish product } \\
\text { authenticity }\left(\mathrm{X}_{10}\right)\end{array}$ & $\begin{array}{l}1=\text { very weak influence } 2=\text { weak influence } 3=\text { general } \\
4=\text { strong influence } 5=\text { very strong influence }\end{array}$ & 3.42 & 0.944 \\
\hline Dependent Variable & & & \\
\hline Whether do online shopping & $1=$ Yes & 0.75 & 0.437 \\
\hline
\end{tabular}


Table 2. Logit Regression Result

\begin{tabular}{llll}
\hline Variable & Coefficient & Wald & Sig. \\
\hline $\mathrm{X}_{1}$ & 0.286 & 0.093 & 0.760 \\
$\mathrm{X}_{2}$ & 2.179 & 2.031 & 0.154 \\
$\mathrm{X}_{3}$ & 0.125 & 0.029 & 0.866 \\
$\mathrm{X}_{4}$ & -0.998 & 0.558 & 0.455 \\
$\mathrm{X}_{5}$ & $2.834^{* *}$ & 4.300 & 0.038 \\
$\mathrm{X}_{6}$ & 2.199 & 2.082 & 0.149 \\
$\mathrm{X}_{7}$ & 1.773 & 1.584 & 0.208 \\
$\mathrm{X}_{8}$ & 0.097 & 0.009 & 0.923 \\
$\mathrm{X}_{9}$ & $3.765^{*}$ & 3.150 & 0.076 \\
$\mathrm{X}_{10}$ & -0.079 & 0.007 & 0.933 \\
constant & $-43.883^{* * *}$ & 7.139 & 0.008 \\
\hline-2 times of logarithmic & 21.715 & & \\
likelihood function & & & \\
Cox \& Snell $\mathrm{R}^{2}$ & 0.534 & & \\
Nagelkerke $\mathrm{R}^{2}$ & 0.790 & & \\
\hline
\end{tabular}

Notice: $* * *, * *$ and $*$ respectively represent significance on level of $1 \%, 5 \%$ and $10 \%$.

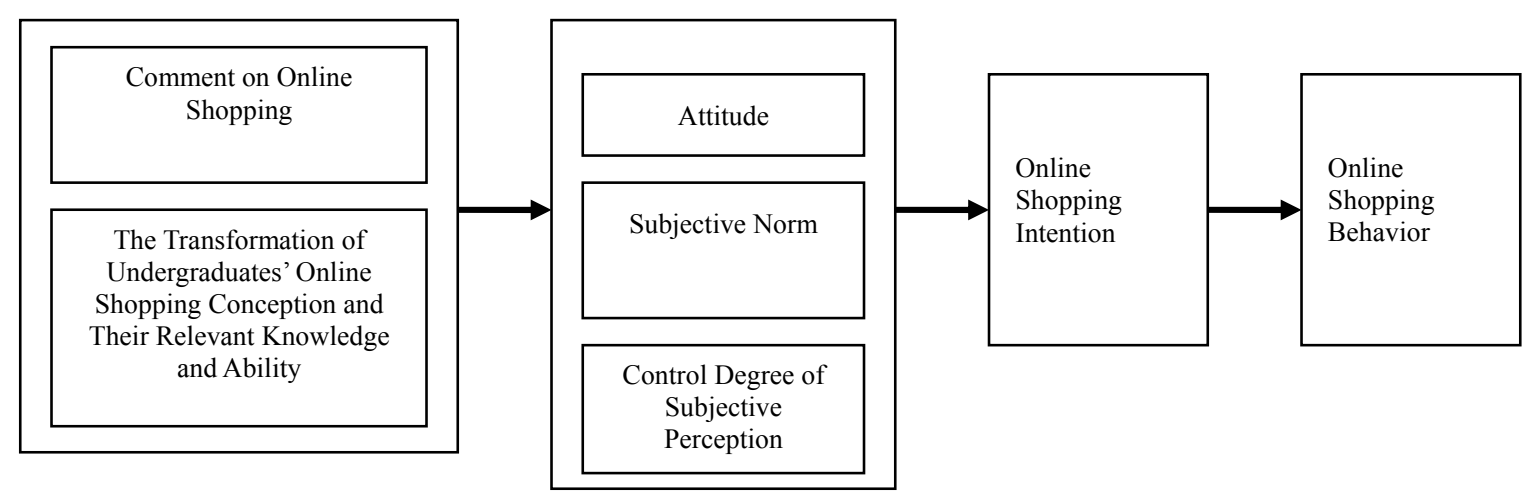

Figure 1. Theoretical Frame on Online Shopping Behavior of Undergraduates 